\title{
Distribution Patterns of Polycyclic Aromatic Hydrocarbons in Marshy Soil and Sediments in Warri, Southern Nigeria
}

\section{Osayomwanbor Ebenezer OGHAMA ${ }^{1}$, Adejoke Victoria BAYOWA2 Iwekumo Ebibofe AGBOZU1}

\begin{abstract}
${ }^{1}$ Department of Environmental Management \& Toxicology, Federal University of Petroleum Resources Effurun, PMB 1221, Effurun, Delta State, Nigeria
\end{abstract}

${ }^{2}$ College of Agriculture and Environmental Science, University of South Africa

\begin{abstract}
This study was carried out to determine the seasonal distribution patterns of Polycyclic Aromatic Hydrocarbons (PAHs) in marshy soil samples in Warri City, Southern Nigeria. The samples were collected during dry and rainy seasons from four locations within Warri and a control location in Agbarho, 20km away. Levels of 16 priority PAHs listed in United States Environmental Protection Agency (USEPA) were determined using Gas Chromatography coupled with Flame Ionization detector (GC-FID). This study was carried from January to March and June to August 2014, representing the dry and wet seasons respectively. Mean levels of individual PAHs for sediment samples in the dry season ranged from $0.001 \mathrm{mg} / \mathrm{kg}$ low for Acenaphthene to $0.447 \mathrm{mg} / \mathrm{kg}$ high for Benzo(a)pyrene while for soil samples in the dry season, mean levels ranged from $0.005 \mathrm{mg} / \mathrm{kg}$ low for Acenaphtylene to $1.069 \mathrm{mg} / \mathrm{kg}$ high for Benzo(a)pyrene. In the rainy season, individual PAH in sediments ranged from $0.001 \mathrm{mg} / \mathrm{kg}$ low in acenaphthylene to $0.231 \mathrm{mg} / \mathrm{kg}$ high for anthracene while for soil samples, mean levels of individual PAHs for rainy season ranged from $0.001 \mathrm{mg} / \mathrm{kg}$ low in phenanthrene to $0.090 \mathrm{mg} / \mathrm{kg}$ high for Benzo(b,k)Fluoranthene. Overall, the highest total concentration of individual PAH was recorded for benzo(a)pyrene with $3.302 \mathrm{mg} / \mathrm{kg}$ in soil samples in the dry season while the lowest total concentration was Acenaphthylene with $0.012 \mathrm{mg} / \mathrm{kg}$ in sediments in the rainy season. It was observed that PAHs concentration was generally higher in dry than rainy seasons for soil and sediment samples. This can be attributed to dissolution and washing-off of the PAHs during the rainy season.
\end{abstract}

Keywords: PAHs; Marshy Soil; Marshy Sediments; Seasonal Distribution Patterns; Benzo(a)pyrene; Gas Chromatography; Flame Ionization detector

\section{INTRODUCTION}

Marshy environments cannot be isolated from the effects of different environmental variables; and soil and sediments may act as a temporary or long-term reservoir of contaminants accompanied by natural origin compounds. Polycyclic aromatic hydrocarbon compounds are omnipresent components of marshy environments and derive from natural and anthropogenic sources. The natural concentration of chemical compounds is characterized as a base and background for identifying the portion of anthropogenic sources $[1,2]$.

PAHs (polycyclic aromatic hydrocarbons) originate mainly from incomplete combustion of organic materials as well as petroleum. Due to their hydrophobic nature, PAHs in the aquatic environment rapidly bind with particles and deposited sediments become their primary reservoirs [3]. The occurrence of PAHs in soils, sediments, aerosols, waters, animals and plants is of increasing environmental concern because some PAHs may exhibit mutagenic [4] properties. The levels of PAHs commonly found in many aquatic environments which are an important risk factor for various health aspects [5]. PAHs represent a major problem to urban environments since these are among the most toxic compounds [6]. Because of their low aqueous solubility PAHs adsorb to particulate material and are deposited in sediments, where they can accumulate in higher concentrations. They also tend to accumulate in biota [4].

This article is published under the terms of the Creative Commons Attribution License 4.0

Author(s) retain the copyright of this article. Publication rights with Alkhaer Publications.

Published at: http://www.ijsciences.com/pub/issue/2017-04/

DOI: 10.18483/ijSci.1194; Online ISSN: 2305-3925; Print ISSN: 2410-4477 
Marshes provide a unique opportunity to assess the chronic input of land-derived pollutants to aquatic ecosystems. Contaminants that accumulate on land and are eroded by rain result in runoff that carries the chemical signature of the land it traverses. Since residential and undeveloped land uses are associated with different levels of PAH accumulation, adjacent wetland sediment should reflect the differences in $\mathrm{PAH}$ concentration as they scavenge particles from runoff [7, 8]. PAH compounds have been listed as priority pollutants by the USEPA (United States Environmental Protection Agency) and the European Union. Consequently, increasing attention has been paid to the environmental behaviour of PAHs on a global scale. This is in addition to their long-range transport potentials; as the global oceans are a likely gigantic sink for organic contaminants derived from a variety of sources [9].

Given the numbers of oil and gas wells and complex transportation pipelines within Warri, determining the concentration levels of PAHs in soil and sediments of this region is necessary for risk assessment and evaluation of ecosystem health. This study was therefore carried out to achieve this aim and also to assess the seasonal variation of PAHs in soils and sediment of the City.

Warri is a major hub of the oil and gas industry in Southern Nigeria. Given the numbers of oil and gas wells and complex transportation pipelines within Warri and its environs, concentration levels of PAHs in soils and sediments of the city must be quantified to evaluate their ecological impacts. Considering that PAHs account for $10-45 \%$ of total hydrocarbons in crude oil $[10,11]$ and the importance of this region to fisheries stock, other edible aquatic lives as well as farming, it is also important to understand the distribution of PAHs in this area. Unfortunately, there is a paucity of data for PAH concentrations and distribution in soils and sediments in Warri City. This study, therefore, is essential not only to determine the seasonal distribution patterns of PAHs in soils and sediments in the city, but also to provide baseline data for the city. Having this type of baseline information available will be critical to developing effective responses to future potential disasters such as oil spills and oil-related disasters.

\section{MATERIALS AND METHOD}

\section{Study Area}

This study was carried out in Warri located between latitude $5^{0} 31^{\prime} \mathrm{N}$ and longitude $5^{\circ} 45^{\prime} \mathrm{E}$. The city, also known as 'Oil City', is one of the cosmopolitan cities and a major hub of petroleum activities and businesses in Southern Nigeria. It is a commercial capital city in Delta State, in the oil rich Niger Delta region, comprising originally of Itsekiri, Urhobo and Ijaw people.

The region experiences moderate rainfall and moderate humidity for most part of the year. The area is characterized by tropical equatorial climate with mean annual temperature of $32.8^{\circ} \mathrm{C}$ and annual rainfall amount of $2673.8 \mathrm{~mm}$. There are high temperatures of $36^{\circ} \mathrm{C}$ and $37^{\circ} \mathrm{C}$. The natural vegetation is a rainforest with swamp forest in some areas. The forest is rich in timber trees, palm trees, as well as fruit trees.

As a result of the unique location of Warri at the bank of the Niger Delta, there are rivers, creeks, ponds and wetland areas around the city hence most places in the city are swampy areas and marshes. Majority of the people especially those living close to the waters are either fishermen/women or take fishing as a hobby. Warri River which is one of the most important coastal rivers of the Niger Delta distributed in various tributaries around the city and beyond is responsible for the marshy soil and swampy area that characterise the city

[12]. 


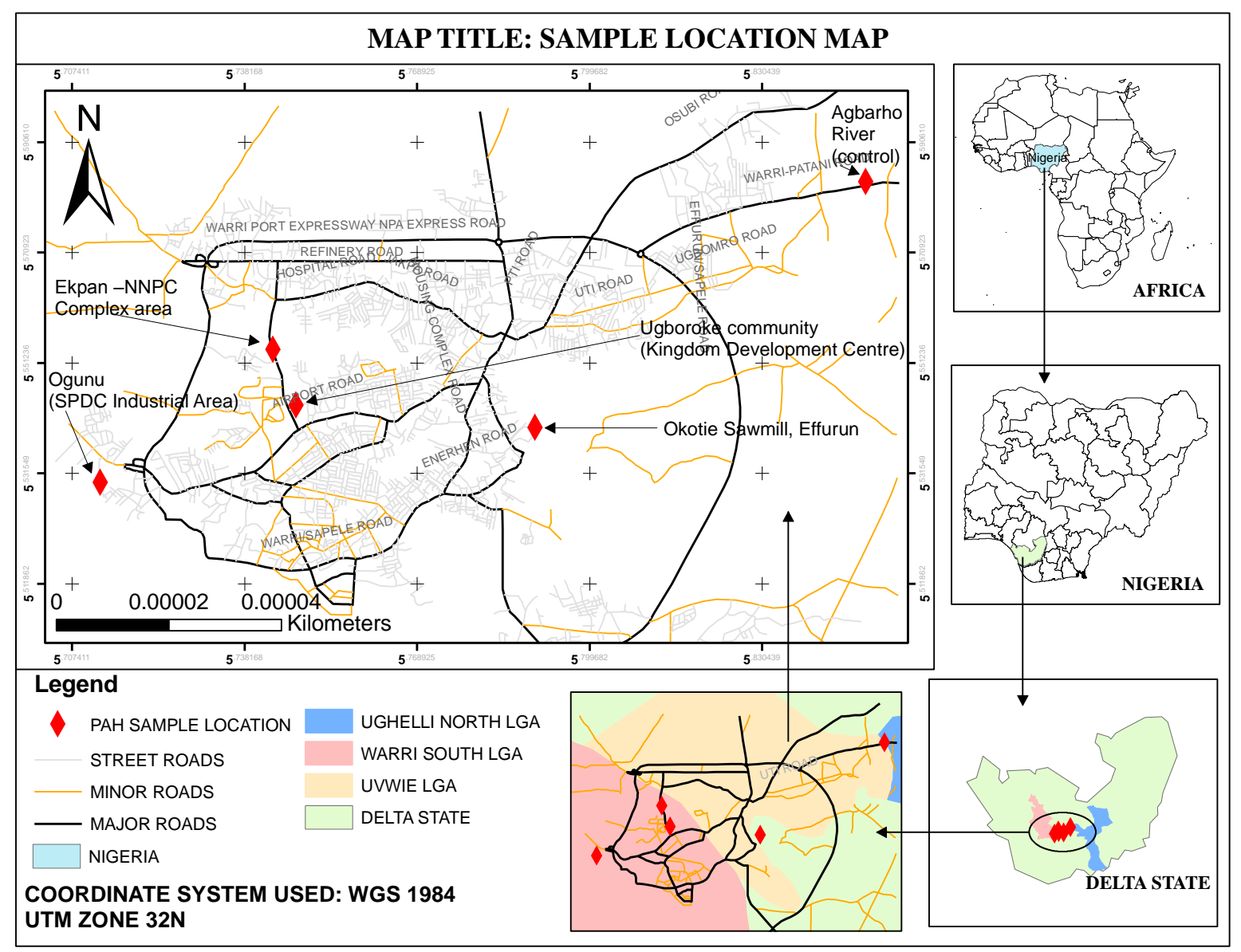

\section{1: GIS based Map of Study Area}

The coordinates of the locations of the sample in the study area are as shown in Table 1 below:

Table 1: Showing Sample Locations and their GPS Coordinates

\begin{tabular}{|c|c|c|}
\hline \multirow[t]{2}{*}{ Sampling Location } & \multicolumn{2}{|c|}{ Coordinates } \\
\hline & Northings & Eastings \\
\hline Ekpan - NNPC Complex Area & $05^{\circ} 33^{\prime} 13.5^{\prime \prime}$ & $005^{\circ} 44^{\prime} 35.8^{\prime \prime}$ \\
\hline Ugboroke community (Kingdom Development Centre) & $05^{\circ} 32^{\prime} 37.6^{\prime \prime}$ & $005^{\circ} 44^{\prime} 50.5^{\prime \prime}$ \\
\hline Ogunu (SPDC Industrial Area) & $05^{\circ} 31^{\prime} 48.1^{\prime \prime}$ & $005^{\circ} 42^{\prime} 44.9^{\prime \prime}$ \\
\hline Okotie Sawmill, Effurun & $05^{\circ} 32^{\prime} 23.3^{\prime \prime}$ & $005^{\circ} 47^{\prime 2} 24.0^{\prime \prime}$ \\
\hline Agbarho River (Control) & $05^{\circ} 35^{\prime} 01.1^{\prime \prime}$ & $005^{\circ} 50^{\prime} 56.0^{\prime \prime}$ \\
\hline
\end{tabular}

\section{Sample Locations}

Five (5) areas were strategically chosen, four within Warri and one outside Warri; the one outside Warri was chosen as the control.

\section{Ekpan-NNPC Complex area}

This site is along the Ekpan bridge express, after the NNPC staff quarters. It is located between longitude $05^{\circ} 33^{\prime} 13.5^{\prime \prime} \mathrm{N}$ and latitude $005^{\circ} 44^{\prime} 35.8^{\prime \prime} \mathrm{E}$. There is a company opposite the sampling point and a church beside it. The exact sampling point is a river under the bridge. One major characteristics of this location is that there are not much human population here but the place is close to NNPC/Ekpan highway a major busy highway. The river could be a drain receiving waste water from neighbouring residential areas and industry.

\section{Ugboroke community Development Centre)}

(Kingdom

This location can be said to describe the natural vegetation of Warri which is of rainforest with swamp forest in some areas; the forest in Warri is rich in timber trees, palm trees, as well as fruit trees. Ugboroke community is however one of the 
emerging areas in Warri and developmental features such as roads, modern building structures are taking over the forest. The community is a densely populated area, made up of local indigenous people as well as others that have come to live within the community. One thing peculiar to this location is that, there are clusters of old, native houses, modern/semimodern residential houses, small and medium scale businesses, factories, and companies, agricultural activities (poultry, fishing amongst others).

The sampling point is a pond at the back of a church (kingdom Development Centre). It is located between longitude $05^{\circ} 32^{\prime} 37.6^{\prime \prime} \mathrm{N}$ and latitude $005^{\circ} 44^{\prime} 50.5^{\prime \prime} \mathrm{E}$. This point is actually like a wetland that is flooded most part of the year. Plantain trees, other trees, shrubs and plants are typical of this environment.

\section{Ogunu (SPDC Industrial Area)}

This site is located between longitude $05^{\circ} 31^{\prime} 48.1^{\prime \prime} \mathrm{N}$ and latitude $005^{\circ} 42^{\prime} 44.9^{\prime \prime} \mathrm{E}$, outside Shell Petroleum Development Company SPDC residential, recreational and mild administrative area. It is a local community that has been upgraded by virtue of the presence of the multinational companies in the area. Apart from SPDC, Ogunu community play host to, Pan Ocean Oil Company. The people in this community are majorly indigenes with few other non-indigenes. Their occupations are majorly petty trading, fishing, farming or idling. The exact sampling point is Ogunu River. There are residential houses around and even in or on the river; there is also a local public toilet and a refuse dump close by.

\section{Okotie Sawmill, Effurun}

This site is located between longitude $05^{\circ} 32^{\prime} 23.3^{\prime \prime} \mathrm{N}$ and latitude $005^{\circ} 47^{\prime} 24.0$ ' ' $\mathrm{E}$, in the outskirt of Warri, in a place called Effurun. To many people, Effurun is not part of the Warri town ship but by geographical and political description, Effunrun is part of the larger Warri City and is usually called together as Effurun Warri. The actual sampling area is a majorly industrial with few residential houses; some of the industries and companies in the area are - Nigeria Bottling Company (Coca Cola) Depot, Phyton Engineering Company, Thermosteel Nigeria Limited, Okotie Plank Sawmill and NISRIN Construction. Okotie Plank Sawmill and NISRIN Construction are just by the river where the sampling was carried out. The sampling point was close to one of the vesselshouseboat constructed by NISRIN.

\section{Agbarho River (Control)}

Agbarho Community is a town outside Warri; it is along the Ughelli/Port Harcourt highway. The actual sampling site is the Agbarho River, located between longitude $05^{\circ} 35^{\prime} 01.1^{\prime \prime} \mathrm{N}$ and latitude $005^{\circ} 50^{\prime} 56.0^{\prime \prime} \mathrm{E}$. Just by the side of this river is an open abattoir and cow meat market; as a result of which there are usually herd of cattle grazing by the side of the river.

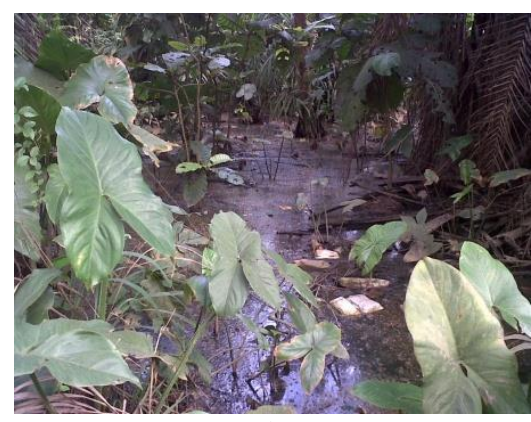

1

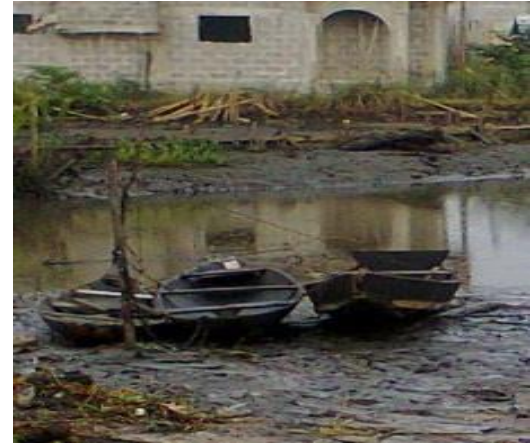

3

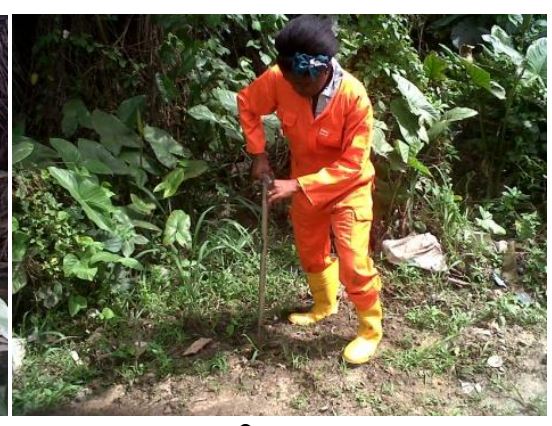

2



4

Plate 1: Ugboroke Community showing the Swampy Forest of Warri; Plate 2: Kingdom Development Centre Ugboroke; Plate 3: Ogunu River; Plate 4: Agbarho Cow Market 


\section{Sample Collection and Analysis}

Soil and sediments samples from the five sampling points were collected in the year 2012 for six months; three months in the dry season (January - March) and three months in the rainy season (June - August). The samples were collected using stainless steel hand auger and stainless steel spoon into an aluminium foil paper; while a stainless steel grab sampler was used for sediment samples that were collected when the river was full. Top $(0-15 \mathrm{~cm})$ and bottom $(15-30 \mathrm{~cm})$ samples were collected at each point to form one composite sample and a total of ten samples were collected for each month in the dry season (JanuaryMarch) and in the wet season (June-August).

The samples were wrapped in aluminium foil and properly preserved by cooling in a refrigerator at $\left(4^{\circ} \mathrm{C}\right)$ before they were taken to the laboratory for analysis. Analysis was done using Gas Chromatography (GC) with Flame Ionization Detector (FID).

\section{RESULTS AND DISCUSSION}

\section{Results}

The results of analyses of the sediment and soil samples from the study area are as presented in Tables 2-6 below with their seasonal variation highlighted in Figures 2 and 3. The results including mean and standard deviation are presented for dry and wet/rainy seasons of sampling. The results were read as the detection limit on the gas chromatogram for individual PAHs which were in microgram per litre and these were converted to milligram per kilogram $(\mathrm{mg} / \mathrm{kg}$.). The minimum detection limit for GCFID used in the analysis on the chromatogram is 1 $\mathrm{x} \quad 10^{-3} \mathrm{mg} / \mathrm{kg}$.

Table 2: PAHs Concentrations in Marshy Soil Samples in Warri City in mg/kg

\begin{tabular}{|c|c|c|c|c|c|c|c|c|c|c|}
\hline \multirow[t]{3}{*}{ PAHs } & \multicolumn{10}{|c|}{ Sampling Stations (ST) } \\
\hline & \multicolumn{2}{|c|}{ ST 1 (Ekpan) } & \multicolumn{2}{|c|}{ ST 2 (Ogunu) } & \multicolumn{2}{|c|}{ ST 3(Ugboroke) } & \multicolumn{2}{|c|}{ ST 4 (Okotie) } & \multicolumn{2}{|c|}{$\begin{array}{l}\text { Control } \\
\text { (Agbarho) }\end{array}$} \\
\hline & $\mathrm{D}$ & $\mathrm{R}$ & $\mathrm{D}$ & $\mathrm{R}$ & $\mathrm{D}$ & $\mathrm{R}$ & $\mathrm{D}$ & $\mathrm{R}$ & $\mathrm{D}$ & $\mathrm{R}$ \\
\hline Naphthalene & 0.09 & 0 & 0.484 & 0 & 0 & 0.017 & 0.584 & 0.012 & 0.195 & 0 \\
\hline $\begin{array}{l}\text { 2-methyl } \\
\text { naphthalene }\end{array}$ & 0 & 0.016 & 0.045 & 0.033 & 0.561 & 0 & 0.04 & 0.192 & 0.007 & 0.411 \\
\hline $\begin{array}{l}\text { 1-methyl } \\
\text { naphthalene }\end{array}$ & 0.082 & 0 & 0.041 & 0.049 & 0.168 & 0 & 0 & 0.038 & 0.009 & 0 \\
\hline Acenaphthylene & 0.01 & 0 & 0.069 & 0.027 & 0 & 0.0003 & 0.025 & 0 & 0 & 0 \\
\hline Acenaphthene & 0.096 & 0 & 0 & 0.018 & 0 & 0.0004 & 0.1 & $\begin{array}{l}0.000 \\
5\end{array}$ & 0.007 & 0 \\
\hline Fluorene & 0 & 0 & 0 & 0.066 & 0 & 0 & 0.082 & $\begin{array}{l}0.000 \\
1\end{array}$ & 0.071 & 0 \\
\hline Phenanthrene & 0.022 & 0 & 0.027 & 0.094 & 0.239 & 0 & 0.139 & 0.003 & 0 & 0 \\
\hline Anthracene & 0 & 0.011 & 0.142 & 0.255 & 0.292 & 0 & 0.113 & 0 & 0.035 & 0 \\
\hline Pyrene & 0.17 & 0 & 0.244 & 0 & 0 & 0.024 & 0.174 & 0.022 & 0.088 & 0.036 \\
\hline Chrysene & 0.11 & 0 & 0.102 & 0 & 0.033 & 0.028 & 0 & 0 & 0 & 0 \\
\hline Benzo(a)anthracene & 0.142 & 0 & 0 & 0 & 1.134 & 0.0964 & 0.159 & 0 & 0 & 0 \\
\hline $\begin{array}{l}\text { Benzo(b)fluoranthren } \\
\text { e\&Benzo(k) } \\
\text { fluoranthrene }\end{array}$ & 0.286 & 0 & 0.11 & 0.275 & 0.076 & 0 & 0.042 & $\begin{array}{l}0.068 \\
2\end{array}$ & 0.514 & 0.053 \\
\hline Benzo(a)pyrene & 0.484 & 0 & 0.362 & 0.1 & 0.318 & 0 & 2.138 & 0.166 & 0 & 0.066 \\
\hline $\begin{array}{l}\text { Indeno(1,2,3- } \\
\text { cd)pyrene \& } \\
\text { dibenzo(a,h)anthrace } \\
\text { ne }\end{array}$ & 0 & 0 & 1.11 & 0.01 & 0 & 0 & 0 & 0.011 & 0 & 0 \\
\hline Benzo(g,h,i)perylene & 0.66 & 0 & 0.479 & 0.223 & 0.309 & 0.07 & 0.226 & 0 & 1.039 & 0.127 \\
\hline Fluoranthrene & 0.074 & 0 & 0 & 0.181 & 0 & 0 & 0 & 0.033 & 0 & 0.046 \\
\hline Total & 2.226 & 0.027 & 3.215 & 1.331 & 3.130 & 0.2361 & 3.822 & 0.546 & 1.965 & 0.739 \\
\hline Mean & 0.139 & 0.002 & 0.201 & 0.083 & 0.196 & 0.015 & 0.239 & 0.034 & 0.123 & 0.046 \\
\hline Standard deviation & 0.189 & 0.005 & 0.294 & 0.097 & 0.301 & 0.029 & 0.527 & 0.060 & 0.277 & 0.104 \\
\hline
\end{tabular}

*D = Dry Season; $\mathbf{R}$ = Rainy Season 
Table 3: Mean Seasonal Concentrations of PAHs in Marshy Soil samples for Warri City in mg/kg

\begin{tabular}{|l|l|l|}
\hline \multirow{2}{*}{ STATION } & \multicolumn{2}{|c|}{ SEASON } \\
\cline { 2 - 3 } & Dry(mg/kg) & Rainy(mg/kg) \\
\hline ST 1 (Ekpan) & 0.139 & 0.002 \\
\hline ST 2 (Ogunu) & 0.201 & 0.083 \\
\hline ST 3 Ugboroke) & 0.196 & 0.015 \\
\hline ST 4 (Okotie Sawmill) & 0.239 & 0.034 \\
\hline Control (Agbarho) & 0.123 & 0.046 \\
\hline
\end{tabular}

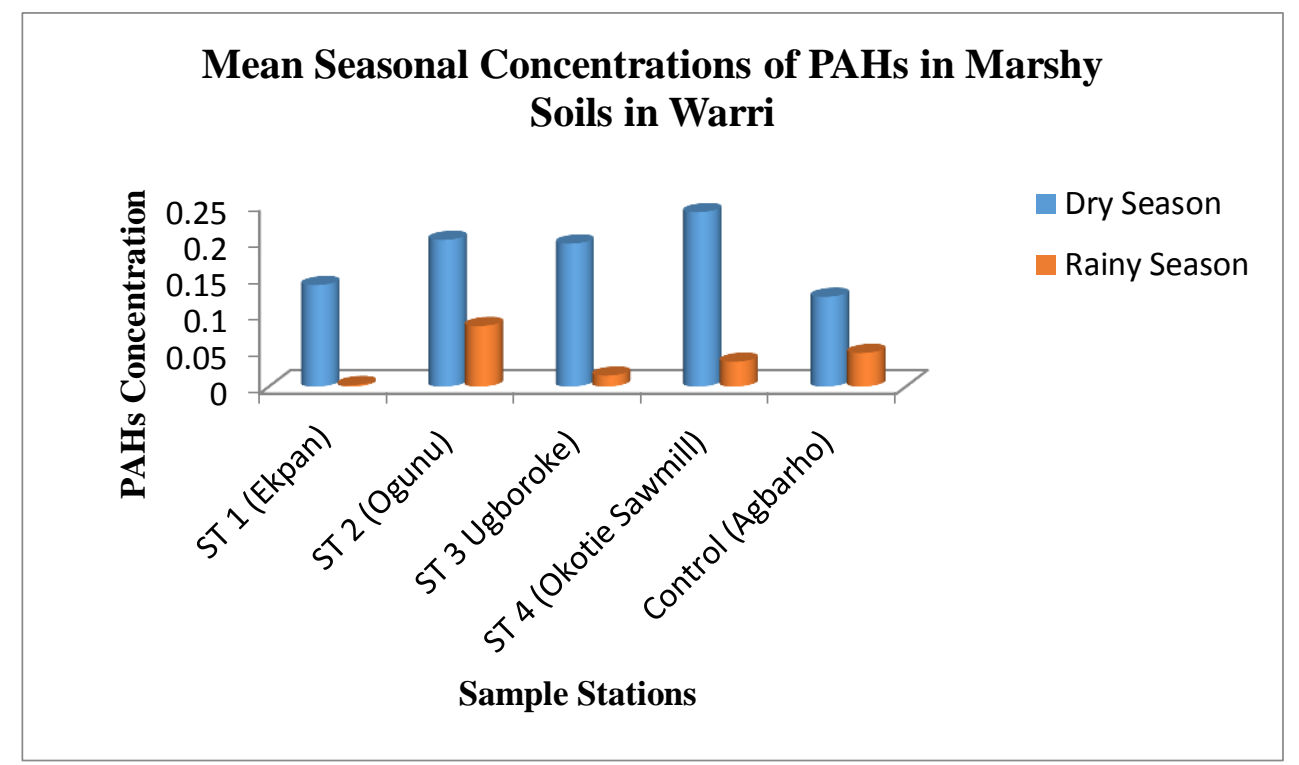

Fig 2: Mean Seasonal Concentrations of PAHs in Marshy Soils in Warri

Table 4: PAHs Concentrations in Marshy Sediment Samples in Warri City in mg/kg

\begin{tabular}{|c|c|c|c|c|c|c|c|c|c|c|}
\hline \multirow[t]{3}{*}{ PAHs } & \multicolumn{10}{|c|}{ Sampling Stations (ST) } \\
\hline & \multicolumn{2}{|c|}{ ST 1 (Ekpan) } & \multicolumn{2}{|c|}{ ST 2 (Ogunu) } & \multicolumn{2}{|c|}{$\begin{array}{l}\text { ST } 3 \\
\text { (Ugboroke) }\end{array}$} & \multicolumn{2}{|c|}{ ST 4 (Okotie) } & \multicolumn{2}{|c|}{$\begin{array}{l}\text { Control } \\
\text { (Agbarho) }\end{array}$} \\
\hline & $\mathrm{D}$ & $\mathrm{R}$ & $\mathrm{D}$ & $\mathrm{R}$ & $\mathrm{D}$ & $\mathrm{R}$ & $\mathrm{D}$ & $\mathrm{R}$ & $\mathrm{D}$ & $\mathrm{R}$ \\
\hline Naphthalene & 0.041 & 0 & 0.211 & 0 & 0.0349 & 0 & 1.091 & 0 & 0.421 & 0.017 \\
\hline $\begin{array}{l}\text { 2-methyl } \\
\text { naphthalene }\end{array}$ & 0.039 & 0 & 0.041 & 0 & 0.0353 & 0 & 0.05 & 0 & 0 & 0.21 \\
\hline $\begin{array}{l}\text { 1-methyl } \\
\text { naphthalene }\end{array}$ & 0.01 & 0 & 0.001 & 0 & 0 & 0.209 & 0.18 & 0.073 & 0.37 & 0.033 \\
\hline Acenaphthylene & 0.007 & 0.005 & 0.006 & 0 & 0.076 & 0 & 0.046 & 0.007 & 0.154 & 0 \\
\hline Acenaphthene & 0 & 0.006 & 0.01 & 0 & 0.004 & 0.008 & 0.0216 & 0.02 & 0 & 0 \\
\hline Fluorene & 0.011 & 0 & 0.057 & 0.13 & 0.013 & 0 & 0.09 & 0.131 & 0.038 & 0.017 \\
\hline Phenanthrene & 0.191 & 0 & 0.07 & 0 & 0.0235 & 0 & 0.245 & 0.228 & 0.577 & 0.046 \\
\hline Anthracene & 0.244 & 0.071 & 0.093 & 0.751 & 0.147 & 0 & 0.338 & 0.693 & 0.075 & 0 \\
\hline Pyrene & 0.209 & 0 & 0.214 & 0 & 0.187 & 0 & 0.513 & 0.361 & 0.186 & 0 \\
\hline Chrysene & 0.507 & 0.617 & 0.49 & 0 & 0.083 & 0 & 0 & 0.285 & 0 & 0.186 \\
\hline $\begin{array}{l}\text { Benzo(a)anthrace } \\
\text { ne }\end{array}$ & 0.144 & 0.452 & 0.255 & 0 & 0.205 & 0 & 0.572 & 0 & 0.18 & 0 \\
\hline $\begin{array}{l}\text { Benzo(b)fluoranth } \\
\text { rene\&Benzo(k) } \\
\text { fluoranthrene }\end{array}$ & 0.413 & 0.52 & 0.193 & 0 & 0.388 & 0 & 0 & 0.245 & 0.104 & 0.109 \\
\hline Benzo(a)pyrene & 0 & 0 & 1.342 & 0 & 0.216 & 0 & 0.823 & 0.422 & 0.779 & 0.068 \\
\hline
\end{tabular}




\begin{tabular}{|l|l|l|l|l|l|l|l|l|l|l|}
\hline $\begin{array}{l}\text { Indeno(1,2,3- } \\
\text { cd)pyrene \& } \\
\text { dibenzo(a,h)anthr } \\
\text { acene }\end{array}$ & 0 & 0 & 0.196 & 0 & 0.267 & 0 & 0.334 & 0 & 1.092 & 0 \\
\hline $\begin{array}{l}\text { Benzo(g,h,i)peryl } \\
\text { ene }\end{array}$ & 0.218 & 0.112 & 0.753 & 0 & 1.067 & 0.147 & 0.139 & 0.346 & 0.202 & 0.282 \\
\hline Fluoranthrene & 0 & 0.01 & 0.04 & 0 & 0 & 0 & 0.097 & 0.218 & 0 & 0.087 \\
\hline Total & 2.034 & 1.793 & 3.972 & 0.881 & 2.747 & 0.364 & 4.540 & 3.029 & 4.179 & 1.055 \\
\hline Mean & 0.127 & 0.112 & 0.248 & 0.055 & 0.172 & 0.023 & 0.284 & 0.189 & 0.261 & 0.066 \\
\hline $\begin{array}{l}\text { Standard } \\
\text { deviation }\end{array}$ & 0.159 & 0.212 & 0.353 & 0.188 & 0.265 & 0.062 & 0.319 & 0.200 & 0.317 & 0.088 \\
\hline
\end{tabular}

*D = Dry Season; $\mathbf{R}$ = Rainy Season

Table 5: Mean Seasonal Concentrations of PAHs in Marshy Sediment samples in Warri City in $\mathrm{mg} / \mathrm{kg}$

\begin{tabular}{|l|l|l|}
\hline \multirow{2}{*}{ STATION } & \multicolumn{2}{|c|}{ SEASON } \\
\cline { 2 - 3 } & Dry(mg/kg) & Rainy $(\mathbf{m g} / \mathbf{k g})$ \\
\hline ST 1 (Ekpan) & 0.127 & 0.112 \\
\hline ST 2 (Ogunu) & 0.248 & 0.055 \\
\hline ST 3 (Ugboroke) & 0.172 & 0.023 \\
\hline ST 4 (Okotie Sawmill) & 0.284 & 0.189 \\
\hline Control (Agbarho) & 0.261 & 0.066 \\
\hline
\end{tabular}

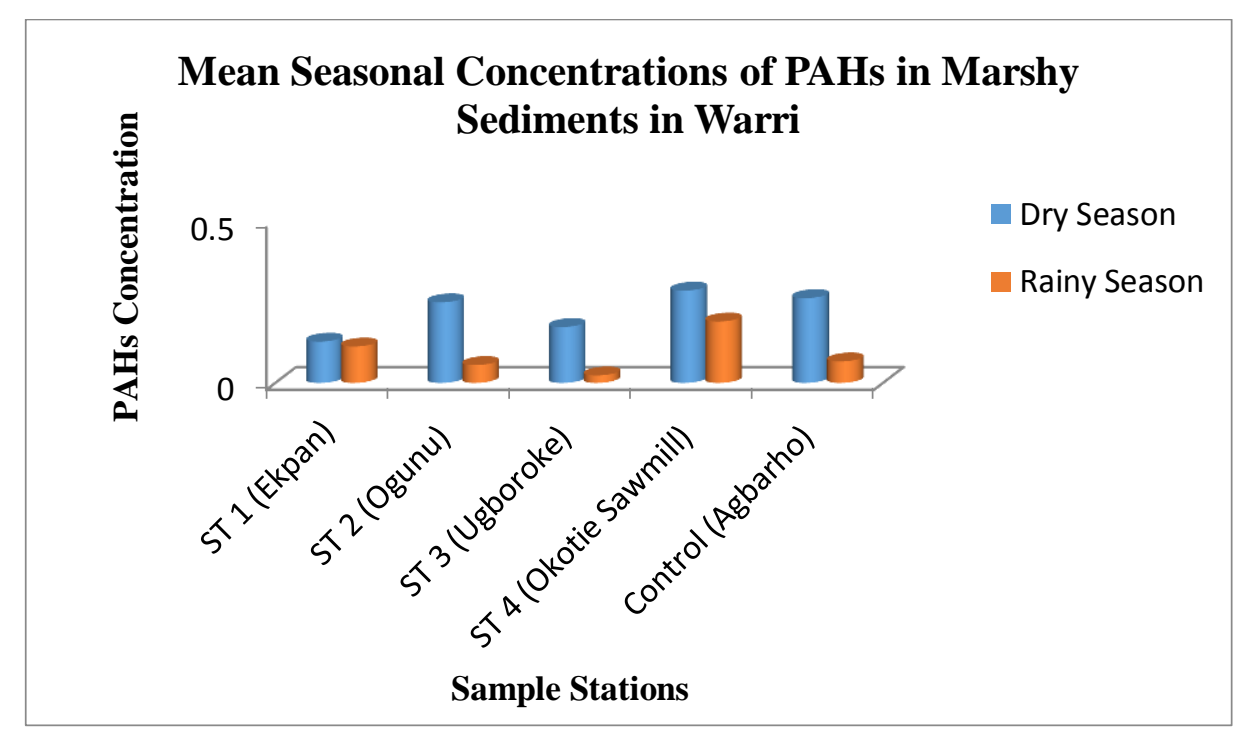

Fig 3: Seasonal Variation of PAHs in Marshy Sediments in Warri

Table 6: Mean Seasonal Concentrations of PAHs in Marshy Soils and Sediment samples for Warri City in $\mathrm{mg} / \mathrm{kg}$

\begin{tabular}{|l|l|l|l|l|}
\hline \multirow{2}{*}{ STATION } & \multicolumn{2}{|c|}{$\begin{array}{c}\text { Dry Season } \\
\text { (mg/kg) }\end{array}$} & \multicolumn{2}{c|}{$\begin{array}{c}\text { Rainy Season } \\
\text { (mg/kg) }\end{array}$} \\
\cline { 2 - 5 } & Soil & Sediment & Soil & Sediment \\
\hline ST 1 (Ekpan) & 0.139 & 0.127 & 0.002 & 0.112 \\
\hline ST 2 (Ogunu) & 0.201 & 0.248 & 0.083 & 0.055 \\
\hline ST 3 (Ugboroke) & 0.196 & 0.172 & 0.015 & 0.023 \\
\hline ST 4 (Okotie Sawmill) & 0.239 & 0.284 & 0.034 & 0.189 \\
\hline Control (Agbarho) & 0.123 & 0.261 & 0.046 & 0.066 \\
\hline
\end{tabular}




\section{Discussion}

\section{Seasonal variation across the sample locations}

During the dry season, the soil PAHs concentration at the different sample locations ranged from 0.123 to $0.239 \mathrm{mg} / \mathrm{kg}$ (Table 6). Okotie Sawmill had the highest concentration of $0.239 \mathrm{mg} / \mathrm{kg}$ while the lowest concentration with a value of $0.123 \mathrm{mg} / \mathrm{kg}$ was obtained at the control location. For sediments, the PAHs concentration ranged from 0.127 to $0.284 \mathrm{mg} / \mathrm{kg}$, the highest concentration $(0.284 \mathrm{mg} / \mathrm{kg})$ was also recorded at Okotie Sawmill while the lowest concentration (a value of $0.127 \mathrm{mg} / \mathrm{kg}$ ) was obtained at Ekpan. The control station (Agbarho) had $0.261 \mathrm{mg} / \mathrm{kg}$.

During the rainy season, the soil PAHs concentration at the different sample locations ranged from 0.002 to $0.083 \mathrm{mg} / \mathrm{kg}$. Ogunu had the highest concentration of $0.083 \mathrm{mg} / \mathrm{kg}$ while the lowest concentration with a value of $0.002 \mathrm{mg} / \mathrm{kg}$ was obtained at Ekpan. For sediments, the PAHs concentration ranged from 0.023 to $0.189 \mathrm{mg} / \mathrm{kg}$, the highest concentration $(0.189 \mathrm{mg} / \mathrm{kg})$ was also recorded at Okotie Sawmill while the lowest concentration (a value of $0.023 \mathrm{mg} / \mathrm{kg}$ ) was obtained at Ugboroke. The control station (Agbarho) had $0.066 \mathrm{mg} / \mathrm{kg}$.

Overall, for both soil and sediments, the PAHs concentration during the dry season ranged from 0.123 to $0.284 \mathrm{mg} / \mathrm{kg}$; with the lowest concentration of $0.123 \mathrm{mg} / \mathrm{kg}$ recorded at the control location and the highest concentration of $0.284 \mathrm{mg} / \mathrm{kg}$ recorded at Okotie Sawmill. During the rainy season (for both soil and sediments), the concentration ranged from 0.002 to $0.189 \mathrm{mg} / \mathrm{kg}$, with the lowest concentration of $0.002 \mathrm{mg} / \mathrm{kg}$ recorded at Ekpan and the highest concentration $(0.189 \mathrm{mg} / \mathrm{kg})$ recorded at Okotie Sawmill.

\section{Occurrence of individual PAHs for Soils and Sediments}

Highest total concentration of PAHs within Warri was recorded for $\mathrm{BaP}$ - benzo(a)pyrene at $3.302 \mathrm{mg} / \mathrm{kg}$ in soil samples. The highest contributor to the bulk was at Okotie Sawmill; this location is the one characterised with the presence of several industrial activities and about $2.138 \mathrm{mg} / \mathrm{kg}$ total concentration was detected there in the dry season soil samples. This is similar to the work done by Ana et al. [13] on PAHs contamination of surface waters in Nigeria Coastal Areas. They reported that the concentration of total PAHs in industrialised areas was three times higher than in the less industrialised area. The order of PAHs concentration in soil within Warri is: $\mathrm{BaP}>\mathrm{BghiP}>\mathrm{BaA}>\mathrm{Naph}>\mathrm{Ind} \& \mathrm{Dbah} \mathrm{A}>2$ M.Naph $>$ BbF $>$ Ant $>$ Pyr $>$ Phenan.

The PAH with lowest concentration in soil in Warri environs is acenaphthalene with a total concentration of $0.018 \mathrm{mg} / \mathrm{kg}$ found in the rainy season. The order for lower PAHs in soils in Warri environs is can $<$ Ind\&DbahA $<$ Acp $<$ Chry.

At the control point, PAHs with highest concentration in soil sample was BghiP; it had a total concentration of $1.166 \mathrm{mg} / \mathrm{kg}$ with the larger amount of $1.039 \mathrm{mg} / \mathrm{kg}$ detected in the dry season. It is important to note that the control point location has cattle grazing ground, an abattoir and meat market. Therefore, the high concentration of BghiP here could be attributed to the microbial production of the PAH due to microbial activities in the abattoir area. This is similar to the study done by Inengite et al. [14] on PAHs sources in Kolo Creek soil in Niger Delta area of Nigeria where it was found that concentration of BghiP was high near an abattoir. The order of PAHs concentration in soil in decreasing order is BghiP $>\mathrm{BbF} \& \mathrm{BkF}>2$ Methyl.Naph. Lowest concentration of total PAHs detected at control station for soil for both dry and rainy season is $0.007 \mathrm{mg} / \mathrm{kg}$, and the order is Acn $\leq 2$ Methyl.Naph $\leq 1$-Methyl.Naph. Most of the PAHs were not found at all and they include: Phe., Acnptyl.,Ind\&DbahA, BaA, and Chry. Those detected only in dry season are: Ant, Fluoren, Acenapthalene, and 1-Methyl Naph; and those detected only in rainy season are $\mathrm{BaP}$ and Fluoranthene.

For sediment samples within Warri environs, PAHs with highest concentration is $\mathrm{BaP}$ - benzo(a)Pyrene with a total concentration of $2.803 \mathrm{mg} / \mathrm{kg}$ and the larger amount of $2.381 \mathrm{mg} / \mathrm{kg}$ being found in the dry season. The decreasing order for total PAHs in sediment sample for dry and rainy season is: $\mathrm{BaP}>\mathrm{BghiP}>\mathrm{Ant}>\mathrm{Naph}>\mathrm{BaA}>\mathrm{Pyr}>\mathrm{Chyr}>\mathrm{BbF} \& \mathrm{BkF}$ $>\mathrm{BaA}>\mathrm{Pyr}>\mathrm{Naph}$. The lowest concentration for PAHs in sediments was recorded for acenaptylene $0.012 \mathrm{mg} / \mathrm{kg}$ in rainy season and for total PAHs in dry and rainy season of $0.070 \mathrm{mg} / \mathrm{kg}$ for acenaphthalene. Some PAHs that were below detection level in the rainy season are: naphthalene, 2 methyl naphthalene and Ind \&DbahA. 
At the control point, highest total concentration of PAHs found in sediment was $1.092 \mathrm{mg} / \mathrm{kg}$ and the mean was $0.364 \mathrm{mg} / \mathrm{kg}$ for Indeno(1,2,3cd)Pyrene\&Dibenz(a,h)Anthracene; all this amount was found only in the dry season as the rainy season record was below detection level. The decreasing order for PAHs in sediments here is: Ind\&DbahA $>\mathrm{BaP}>\mathrm{Phe}$. The PAHs with lowest concentration was fluorene, followed by 1 methyl naphthalene, naphthalene and phenanthrene. Acenapthalene was below detection level in this location while fluoranthene and chrysene were only below detection level in the dry season. Also, Ind\&DbahA, Benzo(a)anthracene, Pyrene Anthracene and Acenaptylene were below detection level in the rainy season.

For Soil samples, the highest total concentration of individual PAH was recorded for benzo(a)pyrene with $3.302 \mathrm{mg} / \mathrm{kg}$ in the dry season while the lowest was Fluoranthrene with $0.074 \mathrm{mg} / \mathrm{kg}$. In the rainy season, highest total concentration of individual PAH was recorded for benzo(b)fluoranthene and benzo(k)fluoranthene at $0.343 \mathrm{mg} / \mathrm{kg}$ while the lowest was Acenaphthene with $0.019 \mathrm{mg} / \mathrm{kg}$.

For Sediments, the highest total concentration of individual PAH was recorded for benzo(a)pyrene with $2.381 \mathrm{mg} / \mathrm{kg}$ in the dry season while the lowest was Acenaphthene with $0.036 \mathrm{mg} / \mathrm{kg}$. In the rainy season, highest total concentration of individual PAH was recorded for Anthracene at $1.515 \mathrm{mg} / \mathrm{kg}$ while the lowest was Acenaphthylene with $0.012 \mathrm{mg} / \mathrm{kg}$; while Naphthalene and 2-methylnaphthalene were not detected.

\section{Seasonal Variation of PAHs in Soils and Sediments \\ Dry Season}

Mean levels of individual PAHs for sediment samples in the dry season for Warri environs ranged from $0.001 \mathrm{mg} / \mathrm{kg}$ low for Acenaphthene to $0.447 \mathrm{mg} / \mathrm{kg}$ high for Benzo(a)pyrene. At the control location, mean values ranged from $0.012 \mathrm{mg} / \mathrm{kg}$ low for Fluorene to $0.364 \mathrm{mg} / \mathrm{kg}$ high for Indeno(1,2,3cd)pyrene \& Dibenz(a,h)anthracene in sediments. For soil samples in the dry season, mean levels of PAHs within Warri environs ranged from $0.005 \mathrm{mg} / \mathrm{kg}$ low for Acenaphtylene to $1.069 \mathrm{mg} / \mathrm{kg}$ high for Benzo(a)pyrene. While in the control point it ranged from $0.003 \mathrm{mg} / \mathrm{kg}$ low for 2 methyl- Naphthalene to
$0.519 \mathrm{mg} / \mathrm{kg}$ high for $\operatorname{Benzo}(\mathrm{g}, \mathrm{h}, \mathrm{i})$ perylene in soil samples.

It can be noticed here that individual PAH levels within Warri was low for three rings - Acenaphtylene and Acenaphthene and high for five-ringed Benzo(a)Pyrene in soil and sediment samples in dry season. This could indicate that the activities within that environment are influencing the soil and the sediment in similar way. However, at the control point, a different trend was seen. PAH levels was low for three-ringed fluorene in soil samples and tworinged naphthalene in sediments while it was high for Indeno (1,2,3-cd)pyrene \& Dibenz(a,h) anthracene in sediments and six-ringed Benzo(g,h,i)perylene in soil samples. This is similar to a study reported in [15], in which was explained that soils and sediments have been found to be good environmental sink for PAHs thereby reflecting their levels in the environment and could contain about $90 \%$ of these compounds with longer half-life than the atmosphere or in plants.

\section{Rainy Season}

In the rainy season, individual PAH in sediments ranged from $0.001 \mathrm{mg} / \mathrm{kg}$ low in acenaphthylene to $0.231 \mathrm{mg} / \mathrm{kg}$ high for anthracene. While at the control, it was $0.005 \mathrm{mg} / \mathrm{kg}$ low in Fluorene to $0.094 \mathrm{mg} / \mathrm{kg}$ high for Benzo(g,h,i)perylene in sediment samples. In soil samples within Warri, mean levels of individual PAHs for rainy season ranged from $0.001 \mathrm{mg} / \mathrm{kg}$ low in phenanthrene to $0.090 \mathrm{mg} / \mathrm{kg}$ high for Benzo(b)Fluoranthene \& Benzo(k)Fluoranthene. At the control point, it was $0.012 \mathrm{mg} / \mathrm{kg}$ low for pyrene to $0.130 \mathrm{mg} / \mathrm{kg}$ high for 2-Methyl-Naphthalene in soil samples. A general observation from PAH levels result in the rainy season, at the study location and the control is that, lower amounts were detected in the rainy season compared to the dry season. It was also observed that mean levels in sediment samples were higher than in soils for this study period. A similar trend was observed in a related study in the Niger Delta area of Nigeria [14]. According to them, during rainy season, it is expected that dissolution and washing-off of the PAHs from the soil matrix could occur into the rivers thereby increasing their levels in sediment. Furthermore, the type of individual PAH detected reflected the activities going on in the environment as three-ringed acenaphthylene and phenanthrene were still relatively low in soils and sediments in Warri environs in rainy season as observed in the dry season. And Benzo(b)fluoranthene \& Benzo(k)fluoranthene which is the five-ringed detected high in soil samples within Warri environs in rainy season has been observed according to the work done by Aubin \& Farant [16], to be more stable and a much better 
marker of PAH source than Benzo(a)pyrene, which was detected high in soil samples in dry season. At the control station, Benzo(g,h,i)perylene which was detected high in soil samples in dry season was found to be high in sediments in rainy season, a likely indication of washing off as observed in [14].

The results from this study show that the type of PAH and their levels in soils and sediments vary for each season under consideration and in this case, dry and rainy season. For soil samples, four ringed pyrene occurred most in the dry season and it was found in the dry season at all the locations for both soil and sediment samples. Also, values for two to three ringed PAHs such as naphthalene and acenaphthene in soils during rainy season were mostly below detection limit of $<0.001 \mathrm{mg} / \mathrm{kg}$. For sediments, the two to three rings were found majorly in the dry season and almost absent in the rainy season. Four ringed PAHs such as chrysene were also found more in the dry season than rainy season for both soil and sediment samples. The five ringed PAHs such as benzo(a)pyrene were found more in the dry season than the rainy season. However, their values vary at different locations in the soil and sediment samples. Six ringed indeno(1,2,3-cd)pyrene was found high in the dry season in control station sediment samples and absent in the rainy season. More different PAHs were detected in the dry season than in the rainy season and overall concentration of PAHs was also higher in the dry season than in the rainy season for soils and sediments samples.

\section{Factors that could be responsible for the Seasonal Variation of PAHs levels}

$\mathrm{PAH}$ in soil is usually from atmospheric deposition due to pyrolytic sources [17]; and the other sources are petrogenic due to petroleum or crude oil activities and spillage. While PAHs in sediments have been found to reflect the history of fossil fuel combustion in the environment [15], and higher molecular weight PAHs which are hydrophobic compounds and have less solubility in water tend to settle in sediments.

Dry season in the Niger Delta which is the area for this study is marked with dust and cool "harmattan" haze and there could be high temperature of $36^{\circ} \mathrm{C}$ and $37^{\circ} \mathrm{C}$. These conditions are favourable for high PAH levels in soil and could be considered to be one of the responsible factors for high PAHs levels in soil samples in dry season for the areas under this study.

According to Adejuwon [18], annual rainfall amount in the study area- Warri, could get to $2807 \mathrm{~mm}$. Apart from usual rainfall in rainy season- May to October, it frequently even rains in the dry season (November to April). Most of the areas in Warri (and mostly the
Niger Delta) are as a result more swampy and marshy with bottom sediments. It was mentioned earlier that PAHs could be washed off (from the atmosphere and soil) during rainy season and are most likely to have undergone reactions that could either increase or decrease their level [14]. According to Brooks [19], when PAHs enter aquatic environment, their fate is determined by the type of compound and the characteristics of the substrate to which they are attached; this is because PAHs are complex compounds and they are hardly found as a single substance. Consequently, PAHs in an aquatic environment could evaporate, disperse into the water column, become incorporated into bottom sediments, and concentrate in aquatic biota or experience oxidation - including photo-oxidation and biodegradation [19]. These factors could be some of the responsible reasons for PAHs high and low levels in sediment in different seasons.

\section{Evaluation of the Effects of PAHs on Man}

Although this study is majorly to determine levels of PAHs in soils and sediments within the study area, an extension to the evaluation of the effects on man is attempted because man is the ultimate consumer in the food chain and would bear the consequences of the presence of these harmful pollutants in the environmental segments.

As earlier stated, most of the places in Warri are swampy and marshy and most of the people especially those living close to the waters are either professional fishermen/women or fish as a hobby. The observed PAHs concentration $(4.840 \mathrm{mg} / \mathrm{kg})$ in sediment samples was above the critical level of $4 \mathrm{mg} / \mathrm{kg}$ recommended by WHO [20] for soils and sediments. PAHs in aquatic environment have been found to be capable of attaching or bioconcentrating in aquatic organisms, mostly bivalve molluscs (such as mussels Mytilus edulis) and oysters of the genera (Ostrea and Crassastrea) and fish as well as other aquatic organisms with highly permeable filtering gills [19]. When man consumes these aquatic organisms as food, they become at risk to the negative effects of these harmful pollutants. According to WHO [20], man is mainly exposed to PAHs from food and ambient and indoor air that have been polluted with PAHs. The PAHs levels in soil samples $(3.634 \mathrm{mg} / \mathrm{kg})$ in the study area was though lower than the WHO critical level of $4 \mathrm{mg} / \mathrm{kg}$, yet even at this concentration may be considered to be harmful since PAHs in soil is partly a deposition from the atmosphere, and soil and sediments are regarded as good environmental sink that contain about $90 \%$ of these compounds with longer half-life than the atmosphere or in plants [15]. 
When these harmful compounds are inhaled or ingested by man they could go through harmful metabolism. Although extensive metabolism of PAHs compounds done through animal studies have shown that food chain bio-magnification of the compounds does not appear to be significant [17], yet evidences exist that PAHs are enzymatically converted to highly reactive metabolites that bind covalently to macromolecules such as DNA and result in mutagenesis and carcinogenesis in experimental animals [21].

\section{CONCLUSION}

The seasonal Polycyclic Aromatic Hydrocarbons (PAHs) distribution in marshy soils and sediment samples in Warri City, Southern Nigeria were examined in this study. During the dry season, the soil PAHs concentration at the different sample locations ranged from 0.123 to $0.239 \mathrm{mg} / \mathrm{kg}$ while for sediments, the PAHs concentration ranged from 0.127 to $0.284 \mathrm{mg} / \mathrm{kg}$. During the rainy season, the soil PAHs concentration at the different sample locations ranged from 0.002 to $0.083 \mathrm{mg} / \mathrm{kg}$ while for sediments, the PAHs concentration ranged from 0.023 to $0.189 \mathrm{mg} / \mathrm{kg}$.

Mean levels of individual PAHs for sediment samples in the dry season ranged from $0.001 \mathrm{mg} / \mathrm{kg}$ low for Acenaphthene to $0.447 \mathrm{mg} / \mathrm{kg}$ high for Benzo(a)pyrene while for soil samples in the dry season, mean levels ranged from $0.005 \mathrm{mg} / \mathrm{kg}$ low for Acenaphtylene to $1.069 \mathrm{mg} / \mathrm{kg}$ high for Benzo(a)pyrene. In the rainy season, individual PAH in sediments ranged from $0.001 \mathrm{mg} / \mathrm{kg}$ low in acenaphthylene to $0.231 \mathrm{mg} / \mathrm{kg}$ high for anthracene while for soil samples, mean levels of individual PAHs for rainy season ranged from $0.001 \mathrm{mg} / \mathrm{kg}$ low in phenanthrene to $0.090 \mathrm{mg} / \mathrm{kg}$ high for Benzo(b)Fluoranthene \& Benzo(k)Fluoranthene. It was also observed that mean levels in sediment samples were higher than in soils for the rainy study period because during rainy season, it is expected that dissolution and washing-off of the PAHs from the soil matrix could occur into the rivers thereby increasing their levels in sediment.

Overall, the highest total concentration of individual PAH was recorded for benzo(a)pyrene with $3.302 \mathrm{mg} / \mathrm{kg}$ in soil samples in the dry season while the lowest total concentration was Acenaphthylene with $0.012 \mathrm{mg} / \mathrm{kg}$ in sediments in the rainy season.

The results from this study show that the type of PAH and their levels in soils and sediments vary for each season under consideration and in this case, dry and rainy season. For soil samples, four ringed pyrene occurred most in the dry season and it was found in the dry season at all the locations for both soil and sediment samples. Also, values for two to three ringed PAHs such as naphthalene and acenaphthene in soils during rainy season were mostly below detection limit of $<0.001 \mathrm{mg} / \mathrm{kg}$. For sediments, the two to three rings were found majorly in the dry season and almost absent in the rainy season. Four ringed PAHs such as chrysene were also found more in the dry season than rainy season for both soil and sediment samples. The five ringed PAHs such as benzo(a)pyrene were found more in the dry season than the rainy season. However, their values vary at different locations in the soil and sediment samples. Six ringed indeno(1,2,3-cd)pyrene was found high in the dry season in control station sediment samples and absent in the rainy season. More different PAHs were detected in the dry season than in the rainy season and overall concentration of PAHs was also higher in the dry season than in the rainy season for soils and sediments samples.

\section{ACKNOWLEDGEMENT}

With great pleasure, I acknowledge the University of South Africa, South Africa for providing the platform to carry out this study.

\section{REFERENCES}

I. Latimer, J.S. and Zheng, J. (2003) Sources, transport and fate of PAH sin the marine environment, in: P.E.T. Douben (Ed.), PAHs: An Ecotoxicological Perspective, Wiley, UK, pp. 9-33.

II. Payne, J.F., Mathieu, A., and Collier, T.K. (2003) Ecotoxicological studies focusing on marine and freshwater fish, in: P.E.T. Douben (Ed.), PAHs: An Ecotoxicological Perspective, Wiley, UK, pp.191-224.

III. Lichtfouse, E., Budzinski, H., Garrigues, P. and Eglinton, T. (1997) Ancient polycyclic aromatic hydrocarbons in modern soils: $13 \mathrm{C}, 14 \mathrm{C}$ and biomarker evidence, Organic Geochemistry 26:353-359.

IV. Boxall, A.B.A. and Maltby, L. (1997). The effects of motorway runoff on freshwater ecosystems: Toxicant conformation, Archives of Environmental Contamination and Toxicology. 33:9-16.

V. Al-Yamani, F.Y., and Prusova, I. (1994) Common copepods of the northern Arabian gulf: Identification guide, Kuwait Institute for Scientific Research 47(13): 156-163.

VI. Hoffman, E.J., Mills, G.L., Latner, J.S. and Quinn, J.G. (1984) Urban runoff as a source of polycyclic aromatic hydrocarbons to coastal waters, Environmental Science and Technology 18: 580-587.

VII. Menzie, A.C., Hoeppner, S.S., Cura, J.J., Freshman, J.S. and LaFrey, E.N. (2002). Urban and suburban storm water runoff as a source of PAHs (polycyclic aromatic hydrocarbons) to Massachusetts estuarine and coastal environment, Estuaries, 25: 165-176.

VIII. US EPA (1993) Introduction to nonpoint source pollution and wetland mitigation, in: Created and Natural Wetlands for Controlling Nonpoint Source Pollution, Smoley, Boca Raton, pp. 7-41. 
IX. Sanger, D.M., Holland, A.F., and Scott, G.L. (1999). Tidal creek and salt marsh sediments in South Carolina coastal estuaries: Distribution of organic contaminants, Archive of Environmental Contamination and Toxicology 3(7): 458-471

X. Vane, C.H., Harrison, I., and Kim, A.W. (2007) Polycyclic aromatic hydrocarbons (PAHs) and polychlorinated biphenyls (PCBs) in sediments from the Mersey Estuary, UK. Sci Total Environ, 374:112126

XI. Barata, C., Calbet, A., Saiz, E., Ortiz, L., and Bayona J.M. (2005) Predicting single and mixture toxicity of petrogenic polycyclic aromatic hydrocarbons to the copepod Oithona davisae. Environ Toxicol Chem, 24:2992-2999

XII. Olomukoro, J.O. and Egborge, A.B.M. (2004). Hydrobiological studies on Warri River Nigeria Part II: Seasonal trend in physicochemical limnology. Trop. Fresw. Biol. 12(1):9-23

XIII. Ana, G.R.E.E, Sridhar, M.K.C and Emerole, G.O (2011). Contamination of Surface waters by Polycyclic Aromatic Hydrocarbons in two Nigerian Coastal Communities. Journal of Environmental Health Research, 11(2): 77-85.

XIV. Inengite, A.K., Oforka, N.C., Osuji, L.C. (2010). Evaluation of Polycyclic Aromatic Hydrocarbons in Sediment of Kolo Creek in the Niger Delta. International Journal of Applied Environmental Sciences. 5(1): 127-143
XV. Malawska, M., Ekonomiuk, A., Wilkomirski, B. (2006); Polycyclic aromatic hydrocarbons in Peat Cores from Southern Poland: Distribution in Stratigraphic Profiles as an indicator of PAH Sources. Mires and Peat 1: Art. 5. (Online: http://www.mires-andpeat.net/pages/volumes/map01/map0105.php)

XVI. Aubin, S.; Farant, J.P. (2000). Benzo(b)fluoranthene, a Potential Alternative to Benzo(a)Pyrene as an Indicator of Exposure to Airborne PAHs in the Vicinity of Soderberg Aluminium Smelters. Air Waste Manag. Assoc., Journal, 50(12): 93-101.

XVII. Agency for Toxic Substances and Disease Registry ATSDR (1999), Toxicological Profile for Total Petroleum Hydrocarbons (TPH). U.S. Department of Health and Human Services: Public Health Service.

XVIII. Adejuwon, J.O (2012) Rainfall Seasonality in the Niger Delta Belt, Nigeria. J. Geogr. Reg. Plann. 5(2): 51-60

XIX. Brooks, M.K., (1997). Literature review, computer model and assessment of the potential environmental risks associated with creosote treated wood products used in aquatic environments; Aquatic environmental sciences, Port Townsend, WA 98368.

XX. World Health Organisation WHO Guidelines for Drinking water Quality. (2003). Polynuclear Aromatic Hydrocarbons in Drinking-water.

XXI. Irwin, R.J. (1997). Environmental Contaminants Encyclopedia, PAHs Entry. National Park Service, Water Resources Division, Water Operations Branch, Colorado State University. 